\title{
Competitive enzyme-linked immunosorbent assay for Treponema pallidum antibodies
}

\author{
A. A. CODD, M. S. SPROTT, H. K. NARANG, P. B. CRONE and R. H. TURNER \\ Public Health Laboratory, Institute of Pathology, Newcastle General Hospital, Westgate Road, Newcastle upon \\ Tyne, NE4 6BE
}

\begin{abstract}
Summary. A competitive enzyme-linked Treponema pallidum immunosorbent assay (CETPIA) was compared with the standard serological tests for syphilis. Of 3081 serum samples submitted, 2883 gave negative results in the CETPIA and the routine screening tests. Positive results were obtained in the CETPIA and in one or more of the specific treponemal tests with 115 samples. Discrepancies in the results of the CETPIA and standard serological tests were found with 83 serum samples, most of these were attributed to biological false positive reactions in the Venereal Disease Research Laboratory (VDRL) test. CETPIA may have a role in the serological diagnosis of syphilis.
\end{abstract}

\section{Introduction}

Infection with Treponema pallidum causes a wide variety of antibodies to be produced. Tests for these fall into two main groups. Those in the first group detect the non-specific anti-treponemal antibodies, and include tests for antilipoidal (reaginic) and treponemal group-reactive antibodies. The second group comprises the specific $T$. pallidum tests. At present the serological diagnosis and monitoring of syphilis depend on combinations of reaginic and specific treponemal tests. In reference laboratories there is need for a simple, inexpensive test which is sensitive in all stages of syphilis, and which lends itself to automation. The enzyme-linked immunosorbent assay (ELISA) was introduced by Engvall and Perlmann $(1971,1972)$. It was applied to the diagnosis of syphilis by Veldkamp and Visser (1975). Further developments included a fourstep ELISA (Farshy et al., 1985), use of a purified recombinant $T$. pallidum antigen (Radolf et al., 1986), and the application of ELISA to the measurement of immunoglobulins $G$ and $M$ (Lindenschmidt et al., 1983).

We have recently developed an ELISA technique for the detection of anti-treponemal antibodies. It is based on the competitive pathway (Wreghitt et al., 1984), in contrast to the antiglobulin method chosen by other workers. This paper describes the procedure and compares the results with those

Received 16 Aug. 1986, revised version received 29 June 1987; accepted 7 Oct. 1987. obtained in the standard serological tests for syphilis.

\section{Material and methods}

\section{Sera}

Tests were performed on 3081 specimens of serum submitted to the Public Health Laboratory, Newcastle upon Tyne. The specimens comprised three groups: (a) Sera submitted for routine screening tests, predominantly from healthy uninfected patients attending antenatal clinics and general hospital in-patients and out-patients. The Venereal Disease Reference Laboratory (VDRL) and $T$. pallidum haemagglutination assay (TPHA) tests were performed. Samples that gave a positive reaction in one or other of these tests were further examined by the fluorescent treponemal antibody absorbed (FTA-ABS) and Treponema pallidum immobilisation (TPI) tests. (b) Sera found to give positive results on screening by other laboratories and sent for additional specific serological tests as above. (c) Sera submitted for diagnosis or monitoring of treatment from patients attending the Department of Genito-Urinary Medicine, Newcastle upon Tyne. VDRL and TPHA tests were performed with additional specific tests where appropriate.

\section{Standard serological tests}

The VDRL was performed according to the manufacturer's instructions (Wellcome Diagnostics, Dartford) as also was the TPHA test (Don Whitley Scientific Ltd, Shipley, West Yorkshire). The TPI and FTA-ABS tests were performed as described by Wilkinson (1972); the only notable difference was the use of Wellcome sorbent in the FTA-ABS test at a working dilution of 1 in 5 . 


\section{The CETPIA test}

Antigen preparation. The Nichol strain of $T$. pallidum was maintained by serial intratesticular passage in cortisone-treated rabbits. In order to extract the organism for passage and use in the TPI test, sliced, removed testes were shaken in $100 \mathrm{mls}$ of phosphate-buffered saline (PBS) at $37^{\circ} \mathrm{C}$ for $2 \mathrm{~h}$. The extract was transferred into a flask and left to stand overnight at $4^{\circ} \mathrm{C}$ to allow red cells and debris to settle. The supernate was centrifuged at $1600 \mathrm{~g}$ for $2 \mathrm{~h}$. The deposit was collected and resuspended in $8 \mathrm{ml}$ of PBS, subjected to three freeze-thaw cycles and sonicated three times at $20 \mathrm{kH}$ at an amplitude of $8 \mu$ for $15 \mathrm{~s}$, allowing $2 \mathrm{~min}$ for cooling between pulses. Several separate antigen extracts were pooled, titrated and divided into aliquots sufficient for only one plate to avoid repeated freeze-thawing. They were stored at $-40^{\circ} \mathrm{C}$ until used.

Antiserum preparation. A specific antiserum to $T$. pallidum was obtained by infecting a cortisone-treated rabbit with the standard inoculum used for passage. After 35 days $50 \mathrm{ml}$ of blood was taken and the serum separated. This serum was designated $\mathrm{A}-\mathrm{T} \mathrm{p}_{1}$. After 50 days the rabbit was bled. This serum was designated $\mathrm{A}-\mathrm{TP}_{2}$. These sera were stored in 2-ml volumes at $-40^{\circ} \mathrm{C}$. Activity was assessed by TPHA titration; A$\mathrm{TP}_{1}$ gave a positive result at a dilution of 1 in 10000 and $\mathrm{A}-\mathrm{TP}_{2}$ at 1 in 40000.

$(F A b)_{2}-H R P$ conjugate preparation. A $1-\mathrm{ml}$ volume of A-TP 1 was treated with $40 \%$ saturated ammonium sulphate solution and the precipitate washed with a further $5 \mathrm{ml}$ of $40 \%$ ammonium sulphate. The globulin fraction obtained was dialysed overnight against three changes of $0.1 \mathrm{M}$ acetic acid-sodium acetate buffer, $p \mathrm{H} 4.5$ and digested for $16 \mathrm{~h}$ at $37^{\circ} \mathrm{C}$ with pure crystalline (ex hog mucosa) pepsin (Sigma) in a ratio of one part of enzyme to 20 parts of protein. The (FAb) ${ }_{2}$ was separated by gel filtration on Sephadex G-100 and concentrated to $1 \mathrm{ml}$ by pressure dialysis. Horseradish peroxidase type VI (Sigma), $10 \mathrm{mg}$, was dissolved in $0.3 \mathrm{~m}$ bicarbonate buffer and activated by the periodate method with dinitrofluorobenzene for site protection. Both the activated HRP and the A-TP (FAb) ${ }_{2}$ preparation were dialysed overnight at $4^{\circ} \mathrm{C}$ against three changes of $0.01 \mathrm{M}$ sodium carbonate-bicarbonate buffer, $p \mathrm{H} \mathrm{9.6}$. The conjugate was prepared by mixing the reactants and leaving at room temperature for $4 \mathrm{~h} ; 5 \mathrm{mg}$ of sodium boronhydride was added and the mixture left overnight at $4^{\circ} \mathrm{C}$ to reduce. The preparation was then dialysed against PBS and stabilised by adding a solution of sucrose, bovine serum albumin (BSA) and merthiolate to a final concentration of $40 \%, 2 \%$ and $0.05 \%$ respectively. The final volume of the A-TP (FAb) ${ }_{2}$-HRP conjugate was $4 \mathrm{ml}$, representing a 1 in 4 dilution of the original neat serum.

A globulin fraction of $\mathrm{A}-\mathrm{TP}_{2}$ was prepared by precipitation of the serum with $40 \%$ ammonium sulphate and redissolving the precipitate to the original volume with distilled water.

Test technique. All tests were performed in the $12 \times 8$ microtitration-tray format. Flat-bottomed well strips in twelves, from Titertek (Flow Laboratories Ltd), previ- ously assessed for consistency of coating, were found to be most suitable. The strips were assembled in plate form and $0 \cdot 1-\mathrm{ml}$ volumes of a 1 in 500 dilution of $\mathrm{A}-\mathrm{TP}_{2}$ globulin fraction in coating buffer $(0.01 \mathrm{M}$ sodium carbonate-bicarbonate, $p \mathrm{H} \mathrm{9.6)}$ were dispensed into each well. The plates were covered and left at room temperature for $4 \mathrm{~h}$ to sensitise. After washing three times with $0.15 \mathrm{M}$ PBS containing $0.1 \%$ Tween 20 , the plates were blocked by adding $0.2 \mathrm{ml}$ of blocking buffer (BB) $(0.15 \mathrm{M}$ PBS, BSA $2 \%$, Tween $200.5 \%$ and merthiolate $0.01 \%$ ) to each well, and left at room temperature for $1 \mathrm{~h}$; the blocking buffer was then removed. An antigen sample, typically $0.25 \mathrm{ml}$, was added to $10.5 \mathrm{ml}$ of $\mathrm{BB}$, mixed, and $0.1 \mathrm{ml}$ was dispensed into each well. The plates were sealed and left overnight at $4^{\circ} \mathrm{C}$ for specific antigen capture. After washing three times with PBS-Tween 20, the plates were ready for use. Undiluted patient's serum $(25 \mu \mathrm{l})$ was dispensed into each well with individual tips or a Costar transplate. Positive and negative sera were included as controls. The A-TP (FAb) ${ }_{2}$ HRP conjugate $(8 \mu \mathrm{l})$ was added to $8 \mathrm{ml}$ of conjugate buffer and mixed thoroughly, and $75 \mu$ l of the conjugate dilution, equivalent to a 1 in 5000 dilution of undiluted $\mathrm{ATP}_{1}$, was added to each well. The conjugate buffer was of similar composition tc BB with the addition of sucrose $4 \%$ to render the mixture isopyknic with neat serum. The plate was sealed and incubated at $37^{\circ} \mathrm{C}$ for $2 \mathrm{~h}$, washed five times with PBSTween, with a soak after the third cycle. An 11-ml volume of the substrate buffer plus substrate for each plate was made up by adding $1 \mathrm{ml}$ of dimethylsulphoxide (DMSO) containing $2.5 \mathrm{mg}$ of tetramethylbenzidine (TMB) to $10 \mathrm{ml}$ of $0.1 \mathrm{M}$ sodium-acetate/citric acid buffer $p \mathrm{H} 5 \cdot 5$, and $25 \mu \mathrm{l}$ of hydrogen peroxide $20 \mathrm{v} / \mathrm{v}$ and mixing; $0.1 \mathrm{ml}$ of this solution was dispensed into each well. After $20 \mathrm{~min}$ the reaction was stopped by adding $0.1 \mathrm{ml}$ of $1 \mathrm{~N}$ sulphuric acid to each well. The plates were read photometrically with a Titertek Multiskan plate reader at $450 \mathrm{~nm}$, with air for the blank reading. Typical negative specimens gave an optical density (OD) of 1.2 $1 \cdot 6$. Inhibition of signal by $\geqslant 50 \%$ was scored as a positive result.

\section{Results}

To demonstrate the bimodal distribution between positive and negative reactions, the $O D$ values of 494 sera expressed to the nearest $5 \%$ of the negative control value are shown in the figure. Taking a cut-off value of $\geqslant 50 \%$ inhibition of signal, 212 tests were positive by CETPIA, two were equivocal, one being just below and one just above the cut off, 279 were negative and one sample gave a 'supernegative result', repeatedly giving an OD value well above 2 . The OD values of the negative sera seen on the right of the figure follow a normal distribution. Although inany of the positive samples gave relatively weak reactions in the standard test, $90 \%$ of the CETPIA-positive samples shown on the left of the figure gave an inhibition of signal of 
$\geqslant 65 \%$. Thus, with CETPIA, in contrast with the standard methods in use, there was good separation between positive and negative results and very few equivocal results.

Results obtained with the 3081 serum samples tested are shown in table I; 2883 specimens of serum gave negative results in the CETPIA and in routine screening tests. A positive CETPIA result was recorded in six samples for which VDRL and TPHA screening tests were found to be negative. One sample was from a patient clinically diagnosed as syphilitic with previously weakly positive serological reactions. Two samples we examined were found to give negative results on routine screening and no further specimens were submitted. A repeat serum from another patient, retested one month later, showed a negative CETPIA result. Sera from the remaining two patients had been submitted for routine screening on at least three previous occasions and had all been found to give negative results.

Of the 3081 serum samples submitted, 192 were examined by additional serological tests, either because they gave positive reactions in one or more of the screening tests, or because the clinical presentation merited full serological investigation (table I). There was agreement between the CETPIA and standard serological tests for 115 samples. In 76 specimens for which the results of one or more of the standard serological tests were recorded as positive, the CETPIA gave a negative result. One specimen gave a positive reaction in the CETPIA although the standard serological tests gave negative results. The serological reactions of these serum samples are given in detail in tables II and III.

The results of CETPIA and all serological tests were positive for 44 samples, and another 26 samples showed consistent positive results except

Table I. Comparison of CETPIA and standard serological test results

\begin{tabular}{ccc}
\hline Number of sera & $\begin{array}{c}\text { CETPIA } \\
\text { result }\end{array}$ & $\begin{array}{c}\text { Standard serological } \\
\text { test results }\end{array}$ \\
\hline 2883 & - & $-+^{*}$ \\
115 & + & $+\dagger$ \\
76 & - & $-\ddagger$ \\
7 & + & + \\
\hline
\end{tabular}

$-=$ Negative result $;+=$ positive result

* VDRL and TPHA only.

† VDRL, TPHA, FTA-ABS and TPI.

$\ddagger$ VDRL and TPHA only, except for one sample with FTA-ABS and TPI also.
Table II. Comparison of CETPIA and standard serological test results with 116 sera that gave positive CETPIA results

\begin{tabular}{cccccc}
\hline CETPIA & VDRL & TPHA & FTA-ABS & TPI & $\begin{array}{c}\text { Number } \\
\text { of sera }\end{array}$ \\
\hline+ & + & + & + & + & 44 \\
+ & + & + & + & - & 26 \\
+ & + & + & - & - & 2 \\
+ & + & - & + & - & 2 \\
+ & - & + & + & + & 3 \\
+ & - & + & + & - & 31 \\
+ & - & + & - & - & 6 \\
+ & - & - & + & - & 1 \\
+ & - & - & - & - & 1 \\
\hline
\end{tabular}

$-=$ Negative $;+=$ positive

Table III. Comparison of CETPIA and standard serological test results with 76 sera that gave negative results in CETPIA and positive results in other tests

\begin{tabular}{ccccccc}
\hline CETPIA & VDRL & TPHA & FTA-ABS & TPI & $\begin{array}{c}\text { Number } \\
\text { of sera }\end{array}$ \\
\hline- & + & $+^{*}$ & - & - & 2 \\
- & + & - & + & - & 1 \\
- & + & - & - & - & 51 \\
- & - & + & + & - & 2 \\
- & - & $+\dagger$ & - & - & 15 \\
- & - & - & + & - & 5 \\
\hline
\end{tabular}

$-=$ Negative $;+=$ positive

* One serum at the screening dilution of 1 in 80 , and one below the screening dilution.

†Eleven sera gave positive reactions below the screening dilution only.

for the TPI test which remained negative (table II). With 34 samples for which the VDRL result was negative, the CETPIA, TPHA and FTA-ABS tests gave positive results with three of these sera, the TPI test was also positive, but in 31 it was negative. With six sera the TPHA and CETPIA alone gave positive results and in one sample the CETPIA and FTA-ABS alone gave positive results. In one sample the CETPIA gave a positive reaction when all other tests gave negative results.

The CETPIA test gave negative results with 76 serum samples in which at least one other serological test gave a positive result. These results are shown in table III. The majority of these (51 sera) gave a positive VDRL result only. With 15 samples the TPHA only was positive, and in 11 of these only at dilutions below the screening titre of 80 . With five samples the FTA-ABS test alone gave a positive result. 


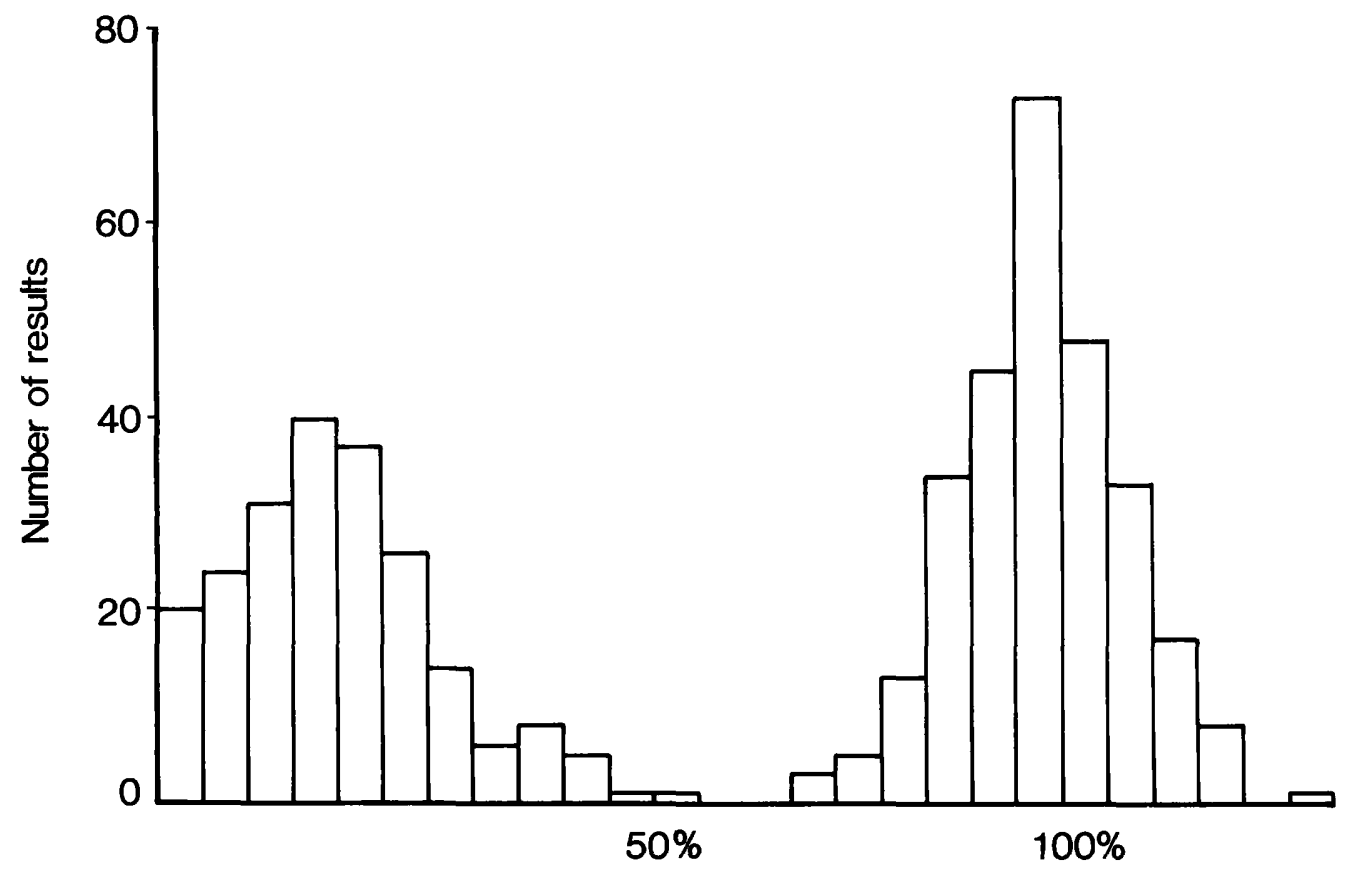

Optical Density (OD)

Figure. Results obtained in CETPIA with 494 serum samples; optical density is expressed as percentage of the control negative value.

\section{Discussion}

In this study CETPIA compared favourably with standard serological tests. The discrepant results in which CETPIA gave the only positive reaction could be due to detection of $T$. pallidum antibody, either in an infected and treated patient when the screening-test results had reverted to negative, or in primary syphilis when the screening-test results had not yet become positive. Alternatively they could be attributed to technical error. Discrepancies in which the CETPIA result was negative and routine serology tests gave positive results were mainly due to biological false positive VDRL reactions. In many instances these would have necessitated examination of further samples and performance of additional tests. Introduction of the CETPIA as a screening test would eliminate this unnecessary recall and retesting.

We have examined three serum samples from patients with yaws. These gave strong positive CETPIA reactions, suggesting that the test may be useful in the detection of exposure to the closely related pathogenic treponeme $T$. pertenue. Also, 100 sera with rheumatoid factor, myeloma proteins or positive Paul Bunnell reactions, gave no false positive results when tested by CETPIA.
The competitive pathway occasionally produces a 'supernegative' result in which the OD exceeds 2 , the upper threshold of the plate reader. This may be due to heavily lysed or contaminated sera or to inadequate plate washing. Although the effect is much reduced by using (FAb) ${ }_{2}$ conjugates rather than whole IgG conjugates, nevertheless, in operation, CETPIA produces a repeatable 'supernegative' at a frequency of 1 in 1000 and although no serum that gave positive results in standard tests showed this effect it would be prudent to test such samples by an alternative method.

Compared with the standard serological tests, the CETPIA has several advantages. The multichannel dispensing equipment ensures rapid and consistent plate preparation and the use of OD values eliminates observer subjectivity. By using a competitive pathway instead of an antiglobulin ELISA, fewer steps and, usually, a shorter total incubation time are required. Also, as ELISA techniques under optimal conditions work below the lattice threshold, CETPIA is both sensitive and very economical in the consumption of reagents. The antigen yield per rabbit, after extraction of treponemes for passage and TPI tests, is sufficient for 3000-5000 tests. One $\mathrm{ml}$ of capture antibody, 
A-TP ${ }_{2}$, provides for 5000 tests and $1 \mathrm{ml}$ of $\mathrm{ATP}_{1}$ after conversion to (FAb) ${ }_{2}$-HRP supplies 40000 tests. The reagents are stable; treponemal antigen shows no loss of potency after storage for 16 weeks at $-40^{\circ} \mathrm{C}$ and $\mathrm{HRP}$ conjugates keep up to 1 year at $4^{\circ} \mathrm{C}$. Plates have been prepared on over 20 separate occasions, the OD of control negative sera ranged from $1 \cdot 2$ to $1 \cdot 6$. Control positive sera gave similar OD reductions between replicates and repeats, and 100 sera replicated and repeated on two or more occasions gave consistent OD values.

The role of the CETPIA in the serological diagnosis of treponemal infection requires further assessment. It has the potential for use as a

\section{REFERENCES}

Engvall E, Perlmann P 1971 Enzyme-linked Immunosorbent Assay (ELISA). Quantitative assay of immunoglobulin G. Immunochemistry 8: 871-874.

Engvall E, Perlmann P 1972 Enzyme-linked Immunosorbent Assay, ELISA. III Quantification of specific antibodies by enzyme-labelled anti-immunoglobulin in antigen-coated tubes. Journal of Immunology 109 : 129-135.

Farshy C E, Hunter E F, Helsel L O, Larsen S A 1985 Four-step enzyme-linked immunosorbent assay for detection of Treponema pallidum antibody. Journal of Clinical Microbiology 21 : $387-389$.

Lindenschmidt E-G, Laufs R, Muller F 1983 Microenzymelinked immunosorbent assay for the detection of specific IgM antibodies in human syphilis. British Journal of Venereal Diseases 59: 151-156. replacement screening test, or at the very least as an additional confirmatory test. Further clinical studies are needed, and at present a comparison of the CETPIA with the standard serological tests to determine its relevance in the initial diagnosis of the patient and in relation to the stage of the disease is under way. However, this preliminary study shows that the CETPIA produces few false positive or equivocal reactions and is both sensitive and specific.

We thank Mrs C. Laidlow and Miss S. Appleby for typing the manuscript, and the staff of the serology and virology departments of the Newcastle Public Health Laboratory for their cooperation in the study.

Radolf J D, Lernhardt E B, Fehniger T E, Lovett M A 1986 Serodiagnosis of syphilis by enzyme-linked Immunosorbent Assay with purified Recombinant Treponema pallidum Antigen 4D. Journal of Infectious Diseases 153: 1023-1027.

Veldkamp J, Visser A M 1975 Application of the Enzymelinked Immunosorbent Assay (ELISA) in the Serodiagnosis of syphilis. British Journal of Venereal Diseases 51 : 227-231.

Wilkinson A E 1972 Serological Tests for Syphilis. In: Laboratory diagnosis of venereal disease, Public Health Laboratory Service Monograph Series No. 1. London, HMSO, pp 1-24.

Wreghitt T G, Tedder R S, Nagington J and Ferns R B 1984 Antibody Assays for Varicella-Zoster Virus: Comparison of competitive enzyme-linked immunosorbent assay (ELISA), competitive radioimmunoassay (RIA), complement fixation, and indirect immunofluorescence assays. Journal of Medical Virology 13: 361-370. 
